This item was submitted to Loughborough's Research Repository by the author.

Items in Figshare are protected by copyright, with all rights reserved, unless otherwise indicated.

\title{
National library websites: how do they market the library?
}

PLEASE CITE THE PUBLISHED VERSION

PUBLISHER

(C) Ashgate Publishing

VERSION

AM (Accepted Manuscript)

LICENCE

CC BY-NC-ND 4.0

\section{REPOSITORY RECORD}

Cleeve, Marigold, and Derek Stephens. 2019. "National Library Websites: How Do They Market the Library?". figshare. https://hdl.handle.net/2134/4147. 
This item was submitted to Loughborough's Institutional Repository (https://dspace.lboro.ac.uk/) by the author and is made available under the following Creative Commons Licence conditions.

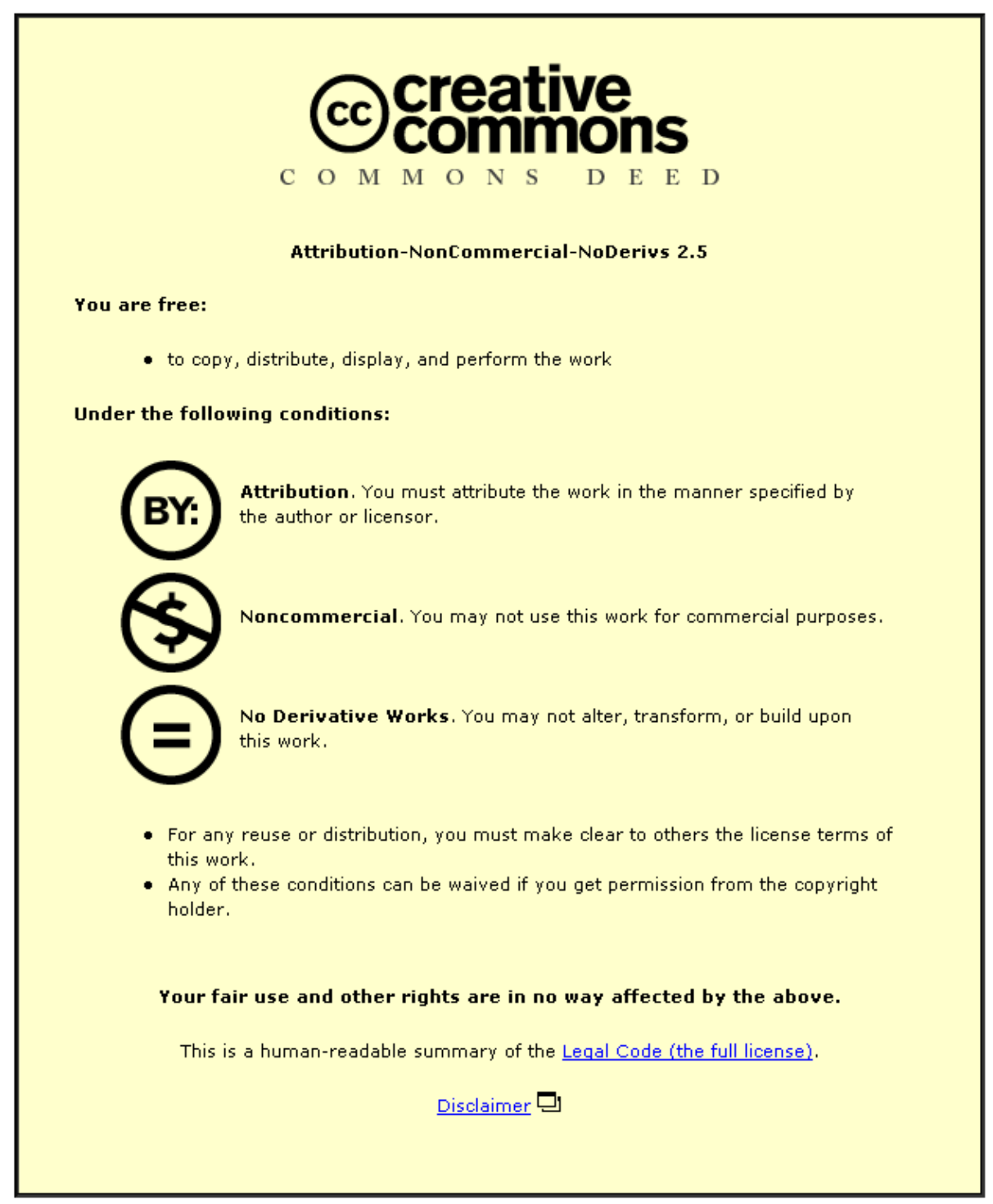

For the full text of this licence, please go to: http://creativecommons.org/licenses/by-nc-nd/2.5/ 


\title{
National Library Websites: How Do They Market the Library?
}

\author{
MARIGOLD CLEEVE AND DEREK STEPHENS
}

Marigold Cleeve is an information consultant, working mainly for the Department of Information Science at Loughborough University. She previously worked in academic libraries for a number of years, and more recently as an Adjunct Lecturer at Loughborough. She has published in information science journals since 1967.

Derek Stephens is a Senior Lecturer and researcher in the Department of Information Science at Loughborough University since 1992. He teaches and supervises in the areas of marketing of information services and libraries, business planning and competitive intelligence. He previously worked in publishing and oil exploration in Canada.

\section{INTRODUCTION}

National libraries cannot easily be visited by users from across the world, or indeed in some places by residents within the country. Their websites thus become the 'long distance' gateways to the libraries and provide an opportunity to communicate their objectives. While marketing has not always been universally accepted within librarianship it is now seen by many as an approach which can assist in such communication. Indeed, within the International Federation of Library Associations and Institutions (IFLA, 2001) guidelines were developed to help gauge the level of marketing being applied. This paper presents a subjective comparative analysis of these 'long distance' findings and outlines evidence of marketing initiatives and a marketing 'mindset' as revealed by the websites of the National Library of New Zealand (Te Puna Mātauranga o Aotearoa), the National Library of Australia, the National Library of Singapore, and the British Library, in November 2007.

For the purposes of this paper the following abbreviations have occasionally been used:

National Library of New Zealand/ Te Puna Mātauranga o Aotearoa (NLNZ)

National Library of Australia (NLA)

National Library of Singapore (NLS)

British Library (BL)

It is useful to note that The National Library of Singapore (NLS) is directed by the National Library Board of Singapore (NLB), which also directs Public Library Services.

\section{BOSTON GUIDELINES}

Pointers to an active marketing front, based on proceedings of the Joint Boston Workshop of the IFLA Section on National Libraries with the Section on Management and Marketing (IFLA 2001) may include the following:

- a library website that is attractive, up-to-date, and easy to comprehend and navigate, and which presents a clear outline of the library's contents and points of access

- a mission statement which indicates the role of the library in supporting national goals

- a marketing and development strategy

- evidence of service improvement to further encourage targeted users to visit the library 
- use of customer surveys (internal and external); collection of data about library users

- active and visible exhibition, publication, tour, concert, lecture and other public programmes

- partnerships that support and reinforce the mission of the library for example with other libraries, museums and archives

The above list represents a commonsense approach, but does not necessarily demonstrate a commitment to a marketing-led approach. Consequently the authors have added the following criteria, based on personal marketing experience in academic and business libraries.

- library branding

- evidence of a strong corporate identity in the library publications

- vision statement to complement the mission statement

- clear indication of the target clients and audiences of the library

- designated staff for marketing, with contact details

- merchandising

- venue hire

- restaurant facilities

- newsletters

- media releases

- presentations and papers about marketing initiatives by the library staff

- active Friends' organization and encouragement of sponsors and volunteers

No library these days can afford to ignore the increasing numbers of clients or potential clients described by Mi and Nesta (2006) as 'The Net generation' and 'visual' or 'digital learners'. National libraries are no exception, and their websites are ideal places to promote the library's collections and activities as well as to provide access to a more global range of information. Marketing aspects listed in the Boston guidelines were considered first, followed by aspects indicating a 'marketing-led' approach, the only exception being vision statements which are considered together with mission statements from the Boston list.

\section{WEBSITES}

The four national library websites were scanned to establish what marketing activities the libraries were involved in, to gain an impression of which constituencies the sites seemed to be designed for, and to ascertain how easy the websites were to comprehend and navigate.

The web sites of the national libraries of New Zealand and Australia provided an interesting example of differing presentational styles. NLNZ had designed an attractive website with an inclusive appeal, using some bilingual (English and Māori) headings and sections. NLA's site used a more traditional, academic approach with the style of a hard-copy rather than an electronic publication. Both provided a site map and a search facility which seemed to work well.

The National Library of Singapore was included in the National Library Board website, and did not have a separate website of its own. This website was quite hi-tech and forwardlooking, with a site map and keyword search facility. It was not always easy to tell, however, whether a hot link on the site would give information on the National Library alone or other parts of the library service run by NLB and it was usually necessary to investigate the link. All the websites included illustrations to good effect, but only Singapore used animation. 
The British Library website outstripped all the other sites in size, with an exhaustive 10,000 pages on the main site but despite its complexity was, nevertheless, well-structured. Colour-coded box headings were used to highlight different sections of the site such as About us (purple), Services (green) and News (deep pink). The home page offered the visitor a range of choices and links as well as a site search box and access to a lengthy site map. Throughout the site a search icon appeared, so that it was possible to wander around the webpages and then refocus, without returning to the home page. According to the BL 'this search facility provides a high-level overview of our four main web resources' (i.e. BL website search, Collect Britain advanced search, catalogue records and journal articles advanced search). The site overall seemed to be appealing to a complete cross-section of users and potential users.

All the national libraries included information relating to their libraries' collections and services together with directional instructions for visitors. Singapore's website presented an extensive electronic version of an 'old-style' library guide, which included a section on Library Etiquette.

\section{MISSION/VISION STATEMENTS}

Mission and vision statements are important tools for fixing the purpose of a library in the public consciousness and a crucial element in establishing its position and relevance to the community it serves. According to Wallace (2004, pp. 8-9) the ideal mission statement is a straightforward statement which communicates 'a clear and measurable statement of intent'. It explains 'why the organisation exists and the difference it makes' and focuses on the library's contribution rather than on the process by which the contribution is achieved. Vision statements reinforce the concept that an organization has a firm role in the near future.

NLNZ presented a concise one sentence summary of vision and values in both English and Māori: 'The National Library's key outcome is New Zealanders connected with information important to all aspects of their lives'. Full Statements of Intent from 2004/5 to 2007/8 were also accessible via a hotlink. In contrast, NLA's site did not present specific mission and vision statements, although some idea of the Library's objectives was given in the Library's Directions 2006-2008, discussed below under 'Marketing/Development strategy'.

Singapore was more forthcoming, with mission and vision statements separately expressed as follows:

Mission: 'To provide a trusted, accessible and globally-connected library and information service so as to promote a knowledgeable and engaged society'.

Vision: 'An inspiring beacon of learning, bringing knowledge alive, sparking imagination, and creating possibility for a vibrant and creative Singapore'.

The British Library's overall mission was the succinct and altruistic 'Helping people to advance knowledge to enrich lives', whereas the full mission statement was, in essence, a type of credo, including phrases such as 'We believe...', 'We bring direct benefits...', 'We play a leading role...'. The vision statement presented a lengthier and strong affirmation of the direction which the BL saw itself as taking and included the clause 'We promote ready access to our collection and expertise through integrated services which are increasingly time and space dependant'. 


\section{MARKETING/ DEVELOPMENT STRATEGY}

A discrete marketing/development strategy is normally the cornerstone of a marketing thrust but although all four national libraries gave access via their websites to their overall strategic direction and plans, access to any separate marketing/public relations strategies was not given. Clues as to marketing direction can, however, often be found within an overall strategic framework as well as from other sources such as presentations and papers by library staff.

In New Zealand, where strategic priorities of the National Library included accessing New Zealand's digital memory, inspiring knowledge creation, enriching the users' experience, Te Kaupapa Mahi Tahi (partnership with the Māori), and valuing strategic alliances, the Chief Executive/National Librarian was supported by Te Komiti Māori, an advisory group on the strategic direction in relation to the Māori. An outline of New Zealand's earlier marketing strategy for 2002 was also found in a report of a presentation by the current Chief Executive's predecessor (Blake, 2002).

On the Australian National Library's website a Statement of Expectations and Intent (as required by the Australian Government) was available. A further document Directions for 2006-2008 defined the Library's main objective for this period, namely 'To enhance learning and knowledge creation by further simplifying and integrating services that allow our users to find and get material, and by establishing new ways of collecting, sharing, recording disseminating and preserving knowledge'. A previous paper by Missingham (2004) on a new strategic direction for the NLA provided useful background material.

Library 2010 (released 2005) available on Singapore's website set out NLB's strategic direction for five years, and was centred on Singapore's move towards a knowledge-based economy and the learning society.

Both the British Library's strategy Redefining the Library...2005-2008 and their Action Plan for 2007/8 were available to download in full-text. Their six strategic priorities were: enriching the user's experience, building the digital research environment, transforming search and navigation, growing and managing the national collection, developing 'our people', and guaranteeing financial sustainability. The BL also mentioned specific development strategies elsewhere in their website in connection with particular sectors such as Collections, Digitization, Diversity and Archiving.

\section{SERVICE IMPROVEMENTS}

Digitization of library holdings featured as an important and ongoing concern on the websites of the national libraries of New Zealand, Australia and the British Library. NLNZ was a major player in the development of the National Digital Heritage Archive of New Zealand, and current initiatives included Matapihi (one-stop access to digital collections of New Zealand's cultural organizations), Discover Te Kohinga Taonga, and the McLean Papers digitization project (material on nineteenth-century race relations). In Australia, all new picture acquisitions were digitized, as well as significant Australian books, serials, manuscripts, maps, printed music and sound recordings, whilst at the BL recent initiatives included the development of the Online gallery and Collect Britain, the latter containing over 90,000 images and sounds from the UK and beyond. The BL had also made considerable progress with the digitization of newspapers, and with collaborative digital repository for research initiatives. Singapore was developing an extensive Web Archive Singapore, a collection of some 1,000 Singapore-related online contents which 'showcase various facets of Singapore life', as well as eCollections (a gateway to NLB digitized and born digital content). 
Building enhancements included the redevelopment of the National Library of New Zealand's Wellington building and the opening of the British Library's new Centre for Conservation. Australia was very much involved in creating a new exhibition space Treasures Gallery, and work was scheduled to begin on this in late 2008.

There were various new service developments in the four libraries. New Zealand had inaugurated a new Family Search Service. Australia highlighted their service Copies Direct, as reported by Missingham, Moreno and Xu (2005). The NLB of Singapore had recently inaugurated an SMS Reference Service where customers could SMS their reference queries to the National Library on their mobile phones. The British Library's innovations in 2007 included a new fee-based scanning service for UK higher education institutions (scanning of materials for inclusion in electronic course packs), and the inauguration of British Library Direct 'a new service which allows users to search across 20,000 journals for free and order full text using a credit card'. The BL's Business and IP Centre had also launched a discussion group for entrepreneurs on the social network Facebook.

\section{CUSTOMER COMMENT/SURVEYS/EVALUATION}

As noted by Elliott de Sáez (2002, p. 146) digital marketing differs from traditional marketing in that the customer can now be treated as a partner in the provision of services. Because of the interactive nature of digital technology, input from the user is greatly facilitated and evaluation of services can be improved. All four national libraries were found to solicit feedback and featured evaluation on their sites.

NLNZ included a statement of Objectives and Service performance in its Annual Report for 2006, while the National Library of Australia's performance against service standards was continuously monitored and recorded in the Annual Report.

Singapore's strategy outlined in Library 2010 included the following statement: 'With the growing complexity of use and the difficulty in justifying cost NLB will embark on specific efforts to measure impact of libraries for both economy and society as a whole'. Customers could give feedback via a QMS line, fax, email: qsm@nlb.gov.sg or by snail mail. Service quality feedback forms were also available in the libraries. In addition, both NLNZ and Singapore operated blogs as a way for clients to keep in touch with the library. NLNZ operated a Create Readers' Blog and a LibraryTechNZ Blog and Singapore's digi.talk (one of NLB's three blogs) was a platform for discussing all things digital at NLB.

The British Library welcomed comments and suggestions via a special webpage with a subheading 'Your views matter to us'. The invitation to comment and make suggestions was also repeated elsewhere on the website. Comments, for example, were invited on the strategic plan and opinions on and suggestions for the various newsletters were sought. Blogs were also operated in connection with workshops and exhibitions. The Learning section of the website encouraged visitors to complete an online survey about their particular interests (presumably to help in the planning of future courses, workshops and events). In late 2007 readers were also being invited to participate in a catering survey.

\section{PUBLIC PROGRAMMES}

Capturing a wide audience is essential in most marketing campaigns, not least for national libraries. Demonstrating the relevance of a library and its collections to the general public is an important element in a successful campaign to gain interest and support. According to Gatenby (2002) some of the ways used by the Australian National Library to capture the attention of a broader audience include using the collections to entertain, revealing the unusual as well as the familiar in the collections, connecting library activities to public 
events, demonstrating the diversity of the collections, and making it easy to find out about and to use the collections.

All four libraries seemed to have active events programmes. Australia, New Zealand and the BL offered a wide variety of events ranging from exhibitions, lectures and talks to workshops, courses for schools, tours and films.

Events programmes were outlined in a What's On listing (Australia and the BL) and also featured in electronic newsletters. The BL's What's On listing, part of their Online Gallery, also included downloads, podcasts and webcasts as well electronic tours, showcases, and feature articles and bookings for British Library tours, workshops, lectures and events could be made via a new Online Box Office. NLB corporate events and promotions were featured on the NLB Digital Library and listings covered all events connected with all libraries under the jurisdiction of NLB, not just the National Library.

Exhibition programmes for the public featured strongly in these events listings for all four national libraries, with online exhibitions becoming widespread. Online exhibitions from the Australian National Library included The World Upside Down: Australia 1788-1830, Federal Fashions, and Bunyips (scary creatures of Aboriginal legends) for schoolchildren. Online exhibitions from the National Library of New Zealand included Contemporary New Zealand Scientists and Rangiätea (the history of the oldest Anglican church in Ötaki, New Zealand). Both NLAU and NLNZ also operated travelling exhibitions programmes at various venues around their respective countries. The British Library provided plenty of choice in their Online Gallery, including Breaking the Rules: the Printed Face of the European Avant Garde 1900-1937, Sacred (sacred texts, including videos and audio) as well as the permanent exhibition Treasures of the British Library. Singapore offered choices with virtual exhibitions including Lim Boon Keng: a Life to Remember and Aksara: the Passage of Malay Scripts.

Workshops were listed by New Zealand, the British Library and Singapore. Singapore's National Library, for example, offered workshops on reading promotion and information literacy. New Zealand offered oral history workshops, including bilingual workshops, for people using oral history in work, community or personal projects. Some BL workshops were targeted at young people in particular age bands, such as a Young Researchers' Project, for 16-19 year-olds. The Business and IP Centre of the BL was also hosting a series of events called Inspiring Entrepreneurs (a celebration of the contribution of black entrepreneurs in Britain today).

New Zealand offered library tours and exhibition tours and Australia offered real time tours as well as an online library tour. On one real time tour you could apparently view the false teeth of a former Prime Minister of Australia but whose teeth they were or how the Library acquired them was not revealed on the website. Only the British Library mentioned that some tours commanded a fee. Guided tours of the public areas of the BL (not the reading rooms) were available at set times each week and cost $£ 8.00$ per person ( $£ 6.50$ concessions). A tour of the Library including one reading room was available on Sundays and Bank Holidays for the same price. Free tours of particular exhibitions were sometimes offered, with discounts in the BL bookshop to tour participants, and free tours of the new conservation centre. There were also two permanent audio guides to the architecture of the building and to the Treasures of the BL. The BL's Learning websites also included virtual exhibitions and themed tours, reflecting the wider public and education programmes being supported. In addition, tours entitled Walks and Talks of London were offered for postgraduates, in the surrounding King's Cross and Bloomsbury areas. Although real time tours of the National Library of Singapore no longer took place, a virtual tour was available. Twice a month there were, however, tours of the National Library Gardens. 


\section{PARTNERSHIPS}

Partnerships have been demonstrated to be very valuable to libraries, and national libraries are no exception. As NLNZ states on its website:

The digital dimension calls for us to adopt and explore new knowledge creation paradigms and for the National Library to be customer centric and responsive to our users both present and future. The role requires someone who is committed ... to partnering with the libraries in New Zealand in delivering knowledge frameworks and services that benefit all New Zealanders (Carnaby, 2007).

Partnering with other libraries of New Zealand and the education, culture and heritage and communication technology (ICT) and research and publishing sectors was one of the four customer-focused value propositions in the strategy of NLNZ to 2017 and the Library was already a major contributor to Metapihi New Zealand cultural database. Australia's National Library supported cooperation and resource sharing through the Libraries Australia service, and this initiative was led by Assistant Directors-General for Resource Sharing and for Innovation (collaborative projects).

Singapore's important collaborations for 2005 (as given in Year in Review) included: Swedish and Danish Embassies, Nestle, Temasek Polytechnic. There was clear evidence of cooperation with other organizations in the NLB's Annual Report 2005/6 (Financial Section. Acknowledgements). Partners and volunteers were also listed, and sponsors and donors. It was difficult to tell, however, whether particular collaborations and partnerships related to public libraries or the National Library, or both. NLB had also signed 'Memoranda of Understanding with various leading libraries in the world to share resources, complement strengths and develop new programmes and services for mutual benefit'.

On the British Library's website cooperation was highlighted. Webpages featured the BL's Regional strategy and Programme, work with public libraries, work with higher education (e.g. JISC partnership projects), working nationally (Full Disclosure, NEWSPLAN, and the National Forum for Information Planning), and working internationally (Consortium of European Research Libraries, ESTC, the European library, the Dunhuang Project, and the Endangered Archives Programme.

\section{LIBRARY BRANDING}

Branding is the first of the 'marketing-led' features additional to the Boston guidelines. All four national libraries used a logo on their website. New Zealand's logo was in the style of a Māori tattoo or decorative design, reinforcing the theme of social inclusion evident elsewhere in the site whereas Australia had chosen a more traditional logo in a blue line-drawing of the National Library building.

Only Singapore gave an explanation for the symbolism of their logo design. Singapore's logo of a stylized open book represented 'qualities of dynamism and the power of unlimited learning; qualities that promote reading, learning and a continual search for information of all forms. The transition from bold solid pages to a pixeled format depicts the evolution from print to electronic media' (NLB Overview, 2007).

The British Library's red and white rectangular box style logo appeared to represent a two-sided book stack. As with the most successful logos, the design was simple but the notion of bookshelves might soon seem outdated in an increasingly electronic age. The logo was, however, designed in conjunction with a branding company and served as the final step 
in a concerted effort to align marketing with the library's objectives over a number of years (Finney, 2006).

\section{CORPORATE POLICY}

Corporate identity is reinforced by the production of good quality corporate publications, whether hard-copy or electronic. All the national libraries provided links on their websites to full and up-to-date policy documents such as the latest annual report.

A substantial annual report for 2006 from The National Library of New Zealand was attractively presented with a modern design, and was far more readable than many of its kind. Te Kaupapa Mahi Tahi 2005-2010 / Plan for Partnership with the Māori 2005-2010 was also available to download as well as yearly targets and Briefing for the Incoming Minister responsible for the national information about the library's roles and activities.

Australia's Annual report (2005-2006) from their National Library was an extensive traditional-style publication. Although this document, which had few illustrations, was not as visually appealing as, for example, the annual report of the BL or the National Library of New Zealand, it would, however, undoubtedly satisfy all the officials and multifarious committees associated with the running of the Library and who were listed in the Report. Other NLA publications available via web links were Directions for 2006-2008, Service Charter (reviewed annually), and Year in Review.

Singapore's NLB website included the NLB Annual Report and a corporate brochure $N L B$ Overview which 'provides information on library services and digital resources as well as collaborations with partner'. A link was also provided to the NLB's publication Year in Review which covered all the libraries for which NLB had responsibility.

For the BL a substantial and well-designed annual report and accounts for 2006/2007 was available online. The title given to this report was My Library which appeared to trade on, but in a curious and converse way, the successful advertising approach of Marks and Spencer plc, with its Your $M \& S$ theme, but raising the question of who, in the case of the British Library, the 'Me' and 'My' might be.

From the overall range of corporate publications, supplemented by information from papers and presentations by library staff, it was possible to gain some impression of the ongoing activities of the four national libraries and of how far marketing techniques had been strategically applied.

\section{TARGET CLIENTS/AUDIENCES}

'Know your publics' is a frequently heard and basic mantra in the marketing world, and certainly four of the national libraries' websites showed evidence that client groups, current and potential, had been analysed.

NLNZ listed library services for young New Zealanders and for researchers as two of the four customer-focused value propositions in strategic directions to 2017 and the Library already provided an International Children's Digital Library link. It certainly also held services to the Māori as a high priority: 'Our role is to enhance Māori participation in all of the Library's business by creating, maintaining, and enhancing meaningful relationships between Māori and the Library' (The Structure of our organisation). A bicultural development programme A plan for Partnership, had been led by John (te Whanau-a-Apanui) Mohi since 1996 and there were also designated links for exploring the Māori world in the Library's collections. Special guidance was also provided for those interested in family history and Whakapapa resources. 
The home webpage of the National Library of Australia provided tailored website links for particular client groups as follows: new users, researchers, family historians, education, libraries, publishers, sponsors and donors, Friends, volunteers and community groups. The Library also had a major directory of holdings relating to Aboriginal Australians, but, unlike the National Library of New Zealand, did not appear on the website to make specific effort to attract Aboriginal citizens to use the Library's facilities, unless the link to Bunyips (See above) was taken into account. The most recent Annual report did state, however, that 'The National Library serves a culturally and socially diverse Australian community and aims to make its collections available to all' (p. 26). It would be interesting to know if there is a strategy for encouraging the Aboriginal Australians to use the Library or to find out, for example, how many Aboriginals currently use the Library.

The Annual Report of the National Library of Singapore paid special attention to the variety of clients who found the National Library essential for their work, studies and general life. The Lee Kong Chian Reference Library offered a variety of fee-based services and products for corporate clients including customized Research Reports, Industry Digests and Industry Trend Alerts and Media Monitoring. The SMS Reference Service targeted a wide variety of clients from entrepreneurs and designers to academics and students in tertiary education.

The British Library defined its broad audience communities under the following headings: researchers, business people, the library network, schools and young people, and the general public. A section of their website was also aimed at potential users in the immediate vicinity What the British Library can offer London highlighted a range of attractions from Inspirational things to see for free, Entertainment and Opportunities to learn to Sound and vision to go and Research resource.

\section{MARKETING STAFF}

It was certainly possible from the websites to identify potential contacts with a marketing brief in the four national libraries. As might be expected a variety of differing structures for marketing staff seemed to be used, although only the British Library provided detailed information.

According to the most recent annual report for 2006/07 the BL directly employed 112 staff in strategic marketing and communication and also used 5 additional external persons for this purpose (British Library, 2007, p.57). The BL team was led by a Director of Strategic Marketing and Communications (DSMC) who was directly responsible to the Chief Executive. The DSMC oversaw public and regional marketing, business marketing, higher education, learning, commercial sales and marketing (publishing and shop), fundraising, product development and publisher relations, communications (corporate, internal, and press and public affairs), web services (Internet and Intranet), and creative services (AV services, corporate design, exhibitions, and corporate copy services). Within this conglomeration the BL had a Development Office, with a Head of Individual Giving to encourage gifts to the Library, including legacy giving.

Interestingly, the BL website section Work with us included in November 2007 a testimonial from a Trust Fundraising Manager employed in their Development Office team and also a separate brief section on Strategic Marketing and Communications in general. The latter included the upbeat statement: 'We're a great $21^{\text {st }}$ century brand'.

The other three national libraries gave only very brief information relating to marketing staff, and only in the upper/middle management levels. It was therefore impossible to tell exactly how many actual staff within these libraries might ultimately be involved in various aspects of marketing. At these senior management levels New Zealand had a 
Communications Advisor for the National Library, and the Alexander Turnbull Library (national documentary collections within the orbit of the National Library) had a Public Relations Manager. The National Library of Australia had an Assistant Director-General of Public Programs, with responsibility for communications and marketing, community heritage grants, development, exhibitions, publications and events. In Singapore marketing responsibilities appeared to be distributed between several Deputy Directors (DDs) of the NLB, namely DDs for Corporate Communications, Publicity and Exhibitions, and Professional and International Relations.

\section{MERCHANDISING}

The sale of products and souvenirs used to be more frequently found in museums and art galleries rather than libraries, but it is now not at all unusual to find a library operating a business enterprise in this way.

Australia's National Library and the British Library both had shops which sold a variety of merchandise as well as books and exhibition souvenirs and both shops had an online ordering facility. NLA's merchandise included mugs embellished with the library logo, key rings, spoons, cards and wrap, posters and prints, and Waltzing Matilda fridge magnets. The BL's shop had recently been expanded to cater for a growing range of gifts, including bags, stationery, chocolate and a wider selection of exhibition-related merchandise. What the British Library can offer London also featured an advertisement for a 'special edition carpet' for sale as an unusual gift. NLNZ apparently had a visitor centre which might sell merchandise, but no further details were available.

In Singapore although there appeared to be a Deputy Director for Publishing and Research Services attached to the National Library, there were no further clues to merchandising apart from a statement relating to multimedia stations for broadband access which commanded a fee for use.

Both the National Library of Australia and the British Library were involved in publishing enterprises, both hard-copy and digital.

\section{VENUE HIRE}

The National Libraries of New Zealand, Australia, Singapore and the British Library all offered venue hire, with the BL providing a 'state of the art' conference centre. For Singapore facilities could be booked electronically from the NLB website.

\section{RESTAURANT FACILITIES}

Two national libraries mentioned their restaurants. NLAU had a restaurant called Bookplate and Leith's at the British Library offered a restaurant and a catering service to support events at the Library and Conference Centre.

\section{NEWSLETTERS}

Keeping your client groups aware of new service developments and opportunities offered by a library is an important element in retaining client loyalty and in engendering interest among potential users, whether in real time or electronically at a distance. Here the provision of electronic newsletters was clearly gaining ground.

The British Library offered the most electronic newsletters, which were freely available. These included Business \& IP Centre News (monthly), Development News (quarterly), 
Higher Education News (bi-monthly), Images Online e-Newsletter (monthly), Learning Newsletter (quarterly), Online Shop, Reader Bulletin (monthly), Research \& Innovation Newsletter (bi-monthly), and What's On. New Zealand offered two e-newsletters: Wellspring/Te Waipuna and Te Ao Hou, the latter being a Māori magazine for school students. The National Library Board of Singapore produced two newsletters, namely@the Library, published bi-monthly, promised to update customers on 'the hottest and latest library events, programmes and initiatives' and Discover $N L B$, a new and lively corporate publication. Both of these included news about the National Library. Online publications from NLA included the National Library of Australia News, a substantial monthly magazine about the Library's collections, services and activities and Gateways, an online journal for the Australian library profession and community.

\section{MEDIA RELEASES}

Informing the media and issuing press releases can be a very effective way of keeping an organization's profile at a high level. New Zealand, Australia, Singapore and the British Library were clearly active in this area and all provided archives of press releases on their websites. NLNZ provided three pages of links to recent press releases on topics ranging from new acquisitions and donating material to funding news and library events. Australia provided media releases for the last three years and Singapore gave a link to a Press Room page where journalists could sign up to receive bulletins as well as view recent press releases. The BL provided numerous press releases on a linked webpage, with a two year archive and the excitement of discovering treasures in the BL was well-conveyed in some of these releases.

New Zealand, Australia and Singapore also provided RSS feeds (automatic updates on new events, news and documents and so on).

\section{PRESENTATIONS/PAPERS}

Professional and academic papers by library staff are usually regarded as heightening a library's profile. The British Library and the National Library of Australia both clearly encouraged their staff to give presentations and contribute to the professional press, and both highlighted these professional contributions on their respective websites. Australia provided an impressive list of all staff publications, with a search facility for authors represented and topics covered. Gatenby, for example, had contributed papers on the marketing of national library collections, and Gatenby (1997) and Pearce (2004) on the use of the World Wide Web to enhance access to the Library's collections. A designated webpage on the BL site provided links to extracts from reports, talks and interviews given or commissioned by the Chief Executive, Lynne Brindley, and a substantial section headed 'Staff Research Profiles' provided details of staff academic interests together with details of their publications.

New Zealand and Singapore seemed mainly represented in the professional press by contributions from their directors. Christopher Blake, the previous National Librarian of New Zealand, gave a presentation at IFLA in 2002 about marketing strategy and initiatives at the National Library of New Zealand (Blake, 2002). R. Ramachandran, the immediate past Director of NLB of Singapore, gave a presentation at IFLA about raising the profile of the NLB (Ramachandran, 2001).

\section{FRIENDS’ ORGANIZATIONS/VOLUNTEERS/SUPPORTERS}


Friends' organizations are frequently found in association with large libraries. Although, especially in the initial founding stage, Friends' organizations can require a measurable amount of staff input, once established they can provide valuable practical assistance and moral support to library staff, and become formidable fundraisers and advocates for the library. Volunteer schemes similarly encourage community involvement, reinforcing the idea of the library as a community resource, although such schemes can encounter problems such as the need for additional supervision and training of volunteers by permanent staff.

According to the websites all four national libraries had Friends' organizations associated with them. NLNZ, moreover, had more than one such organization in association, being supported by Friends of the Turnbull Library and Friends of the Dorothy Neal White Collection. Their list of friends and advisors also included Guardians/Kaitiaki, Komiti Māori, LIAC, LIANZA, National Library Society, NOHANZ, New Zealand Conservators of Cultural Materials, and SLANZA.

NLA had one main friends' organization, Friends of the National Library of Australia. Supporters of the library were, however, also being encouraged to become 'Treasured Partners' in the Treasures Gallery Project. Australia also had a well-developed volunteer programme, with a Volunteer Policy which included special Mission and Vision Statements specifically relating to the Volunteer Programme.

In Singapore the situation was slightly different in that the Friends of the Library (FOL) organization related to all the libraries under the jurisdiction of NLB, and not just the National Library. A special Friends of the Library portal was provided within the website, from which it seemed that a Friend was by definition also a volunteer. FOL provided volunteers for a wide range of duties from promotional activities and event management and support to user and IT education and library patrols. Some volunteers/friends had been trained as tour guides for the National Library.

The British Library had a fairly extensive Support Us section on their website. Members of the public were invited to support the Library in various ways (by making a donation, adopting a book, becoming a Friend or a Patron, and by legacy giving). The Friends of the BL (of which there were over 3,000 members) enjoyed special privileges including a special programme of visits, lectures and events, and access to a Members' Room in the Library. The BL also operated an American Trust, through which tax-efficient donations could be made. It was also possible for a company to become a corporate supporter and enjoy 'distinctive hospitality and communication opportunities'. Current patrons, sponsors and corporate partners were listed by name and included Michael Palin, Goldman Sachs, HSBC and Microsoft.

\section{CONCLUSION}

Pisanski and Žumer (2005, p.51) asserted that the websites of national libraries were about more than providing access to collections; other elements such as selling, advertising, information and announcements, creating discussions and nurturing communities were also important. Analysis of the websites of the national libraries of New Zealand, Australia, Singapore and the British Library certainly produced evidence that all four national libraries were involved in marketing initiatives to a considerable extent. Such websites, therefore, have an additional function and use as a showcase for the library, not just to display its contents, but also to explain its aims and vision and the opportunities it affords, as well as its achievements.

\section{REFERENCES}


Blake, Christopher (2002) 'Marketing national libraries: cultural programmes, exhibitions, WWW ... National Library of New Zealand', http://www.ifla.org/iv/ifla67/papers/blake.pdf (visited 05.12.07).

British Library (2007) My library: British Library annual report and accounts 2006/07. London: HMSO, 2007.

Carnaby, Penny (2007) 'National Library of New Zealand appoints Director, National Digital Library. [Press release], 11 September 2007'. Link via http://natlib.gov.nz/aboutus/news/media-releases (visited 05.12.07).

Elliott de Sáez, Eileen (2002) Marketing concepts for libraries and information services. $2^{\text {nd }}$ ed. London: Facet, 2002.

Finney, Jill (2006) 'Library and information management case studies. Subject: Strategic marketing, British Library', http://www.ics.heacademy.ac.uk/limes/resources/limes_profile_3/index.htm (visited 05.09.08).

Gatenby, Pam (1997) 'New approaches to access: use of the WWW by the National Library of Australia to enhance access to its heritage collections. Paper presented at Information “Online \& On Disc 97”...1997', http://www.nla.gov.au/staffpaper/pgatenby1.html (visited 01.12.07).

Gatenby, Pam (2002) 'National libraries: not for researchers only. How to market the content of national libraries', http://www.ifla.org/IV/ifla67/papers/gatenby.pdf (visited 01.12.07).

IFLA (2001) 'Marketing national libraries, Workshop Report, $67^{\text {th }}$ Council and General Conference, Boston MA, USA', http://www.ifla.org/VII/s34/wsreport01.htm_(visited 15.10.07).

Mi, Jia and Nesta, Frederick (2006) 'Marketing library services to the Net generation'. Library Management, 27(6/7), 2006, pp. 411-422.

Missingham, Roxanne (2004) 'A new strategic direction for the National Library of Australia'. Alexandria, 16(1), 2004, http://www.nla.gov.au/nla/staffpaper/2004/missingham3.html (visited 17.01.08).

Missingham, Roxanne, Moreno, Margarita and Xu, Anne (2005) 'Copies Direct: an innovative service from the National Library of Australia'. Australian Library Journal, 54 (4) 2005, http://www.nla.gov.au/nla/staffpaper/2005/missingham10.html (visited 27.10.07).

National Library Board (2007) 'NLB Overview', http://www.nln.gov.sg/CPMS.portal?_nfpb=true\&_pageLabel=NLBOverview (visited 15.11.07).

Pearce, Judith (2004) 'Building a national library website: work in progress at the National Library of Australia'. Australian Academic and Research Libraries, 35(4), 2004, pp. 214 225, http://www.nla.gov.au/nla/staffpaper/2004/pearce2.html (visited 09.11.07).

Pisanski, Jan and Žumer, Maja (2005) 'National libraries and their websites'. Alexandria, 17(1), 2005, pp. 49-58.

Ramachandran, R. (2001) 'Raising the profile of NLB: the '5+5' strategy', http://www.ifla.org/IV/ifla67/papers/ramachandran.pdf (visited 25.11.07).

Wallace, Linda K. (2004) Libraries, mission, \& marketing: writing mission statements that work. Chicago: American Library Association, 2004.

\section{OTHER RELEVANT DOCUMENTS}

Brindley, Lynne (2005) 'The British Library: its origins, development and future'. Interlending \& Document Supply, 33(2), 2002, pp. 76-80. 
Brindley, Lynne (2006) 'Re-defining the library'. Library Hi Tech, 24(4), 2006, pp. 484-495. British Library (2007) [Homepage] http://www.bl.uk (visited 05.12.07).

Finney, Jill (2003) 'Brand values at the BL'. Update, 2(2), 2003, pp. 54-55.

Library Information Management Employability Skills (LIMES) (n.d.) 'Marketing package 3. Topic: How to successfully re-brand in the information world: a case study of the British Library. Tutor's guide', http://www.ics.heacademy.ac.uk/limes/ (visited 15.10.07).

National Library of Australia. [Homepage] http://www.nla.gov.au

National Library of New Zealand. [Homepage] http://www.natlib.govt.nz

National Library Board Singapore [Homepage] http://www.nlb.gov.sg

Osborne, Mick (2001) 'How to market the content of the national libraries'. [Presentation by the Channel Marketing Manager of the British Library to the IFLA National Libraries Section, Boston, Mass., 2001.] http://www.ifla.org/vii/s1/news/june02.pdf (visited 12.10.07).

Warnaby, Gary and Finney, Jill (2005) 'Creating customer value in the not-for-profit sector: a case study of the British Library'. International Journal of Nonprofit and Voluntary Sector Marketing, 10 (August), 2005, pp. 183-195.

\begin{abstract}
This article presents a comparative analysis of evidence of marketing initiatives as revealed by the websites of the national libraries of New Zealand, Australia, Singapore, and the British Library in November 2007. The analysis is based on criteria set by the joint Boston Workshop of the IFLA Section on National Libraries with the Section on Management and Marketing in 2001. These criteria include an attractive, easily navigable website, library branding, mission and vision statements, marketing and development strategy, number of marketing staff, details of library's contents and points of access, target audiences, service improvements, customer surveys, active and visible public programmes, merchandising, media releases, partnerships with other organizations, active Friends' groups, and encouragement of sponsors and volunteers. Evidence from the websites indicates that all four national libraries appear to be involved in marketing to a considerable extent, and are using their websites to reinforce their marketing efforts.
\end{abstract}

